\title{
PENGARUH KEPEMIMPINAN KEPALA SEKOLAH DAN BUDAYA ORGANISASI TERHADAP MOTIVASI KERJA GURU HONORER SEKOLAH DASAR NEGERI DI KECAMATAN SELAPARANG KOTA MATARAM
}

\author{
M. Chairul Anam, Sudirman Wilian, Dadi Setiadi \\ Program Studi Magister Administrasi Pendidikan Universitas Mataram \\ Email: s2apunramanam@gmail.com
}

\begin{abstract}
ABSTRAK: Penelitian ini bertujuan untuk mengetahui Pengaruh Kepemimpinan Kepala Sekolah Dan Budaya Organisasi Terhadap Motivasi Kerja Guru Honorer SDN di Kecamatan Selaparang Kota Mataram.Metode yang digunakan adalah kuantitatif deskriptif.Teknik pengumpulan data menggunakan angket skala sikap.Hasil analisis regresi diketahui terdapat pengaruh yang signifikan variabel kepemimpinan kepala sekolah terhadap motivasi kerja guru honorer. Hal ini dibuktikan dengan nilai thitungsebesar 2,391 lebih besar dari nilai $\mathrm{t}_{\text {tabel }}$ yaitu sebesar 2,021 ( $\left.\mathrm{t}_{\text {hitung }}=2.391>\mathrm{t}_{\text {tabel }}=2,021\right)$ dengan tingkat signifikansi sebesar 0,021 $<0,05$. Sementara variabel Budaya Organisasi juga berpengaruh signifikan terhadap Motivasi Kerja Guru Honorer, ini dibuktikan dengan nilai $\mathrm{t}_{\text {hitung }}$ sebesar 7,999 lebih besar dari nilai $\mathrm{t}_{\text {tabel }}$ yaitu sebesar 2,021 ( $\left.\mathrm{t}_{\text {hitung }}=7.99>\mathrm{t}_{\text {tabel }}=2,021\right)$ dengan tingkat signifikansi $0,000<$ 0,05. Dari uji model regresi, didapatkan model persamaan regresi pengaruh dari kedua variabel terhadap variabel motivasi dengan model persamaan $\mathrm{Y}=1,194(\alpha)-0,92(\mathrm{KPS})+0,956(\mathrm{BO})+0,415()$. Artinya secara bersama-sama, kedua variabel $\mathrm{X}$ terbukti berpengaruh terhadap motivasi kerja guru honorer. Ini bisa dilihat dari nilai hasil uji $\mathrm{F}$ yang sudah dilakukan, dimana nilai $\mathrm{F}_{\text {hitung }}$ sebesar 32,009, lebih besar dari nilai $F_{\text {tabel }}$ sebesar 3,22. Dengan demikian, direkomendasikan bahwa kepemimpinan kepala sekolah dan budaya organisasi perlu disinergikan untuk meningkatkan motivasi kerja guru honorer. Namun dari hasil penelitian tersebut prioritas utama peningkatan adalah pada budaya organisasi itu sendiri, karena variabel ini terbukti memiliki pengaruh yang lebih besar dari variabel kepemimpinan kepala sekolah (7,99 > 2,391) terhadap motivasi kerja guru honorer.
\end{abstract}

Kata kunci:Kepemimpinan Kepala Sekolah, Budaya Organisasi, Motivasi Kerja Guru Honorer.

\begin{abstract}
The method where is used quantitative descriptive. Data collection techniques using attitude scale questionnaire. Results of regression analysis found a significant difference variables of school leadership to motivation work part time teachers. This is evidenced by $t_{\text {arithmetic }}$ value of 2.391 is greater than the value of the $t$ tabel that is equal to 2.021 ( $t$ arithmetic $=2.391>t_{\text {table }}=2.02$ ) with a significance level of $0.021<0.05$. While the organizational culture variables also significantly influence the Honorary Teacher Work Motivation, is evidenced by $t_{\text {arithmetic }}$ value of 7.999 is greater than the value of the $t_{\text {table }}$ that is equal to $2.021 \quad\left(t_{\text {arithmetic }}=7.999>t_{\text {table }}=\right.$ 2.021 ) with a significance level of $0.000<0.05$. From the test regression model, obtained regression model of the effect of both variables to variable motivation with the model equation $Y=1.194(\alpha)-0,92(K K S)+0.956(B O)+$ 0.415 ( ). This means that together, the two variables $X$ proven to affect the motivation to work part time teachers. It can be seen from the value of the $F$ test results that have been done, where the value $F_{\text {arithmetic }} 32.009$, greater than the value of $3.22 \mathrm{~F}$ table. Thus, it is recommended that school leadership and organizational culture needs to be synergized to increase the motivation of part time teachers. However, from the results of the study the main priority is the improvement of the organizationalculture itself, because these variables proved to have a greater influence than the variable of school leadership (7.99 > 2.391) on work motivation honorary teachers.
\end{abstract}

Keywords: Principal Leadership, Organizational Culture, Honorary Teacher Work Motivation. 


\section{PENDAHULUAN}

Perkembangan pembangunan yang semakin cepat di segala dimensi kehidupan telah mendorong masyarakat Indonesia untuk terus meningkatkan kualitas Sumber Daya Manusia (SDM) nya. SDM yang berkualitas hanya bisa diraih dengan proses pendidikan yang berkualitas pula. Pendidikan merupakan unsur terpenting dalam mencerdaskan kehidupan bangsa. Tidak ada satu bangsa atau negara yang bisa maju tanpa terlebih dahulu memajukan sektor dunia pendidikan.

Untuk mewujudkan hal tersebut diperlukan adanya komponen yang mendukung yakni motivasi kerja guru yang harus ditingkatkan agar mereka lebih profesional. Motivasi kerja guru merupakan suatu proses yang mengarahkan dan mendorong guru dalam melaksanakan tugas pembelajaran di madrasah dan bertanggungjawab atas peserta didik di bawah bimbingannya dengan meningkatkan prestasi belajar peserta didik dan prestasi guru itu sendiri. Oleh karena itu, Uno (2013: 71) menyatakan motivasi kerja guru diartikan sebagai suatu proses yang dilakukan guru agar prilaku mereka dapat diarahkan pada upaya upaya yang nyata untuk mencapai tujuan organisasi yang telah ditetapkan.

Berdasarkan hasil wawancara dengan pengawas dan kepala SD kota Mataram, diperoleh informasi tentang kinerja guru Honorer SD Negeri di Kota Mataram. Beberapa informasi itu merujuk kepada kurangnya kinerja guru honorer di sekolah, di antaranya: (1) Masih 55\% guru yang belum dapat menciptakan kondisi belajar yang baik di dalam kelas, sehingga terlihat siswa kurang aktif dalam pembelajaran; (2) 60\% guru yang hanya mengerjakan tugasnya semau-maunya seperti halnya guru hanya memeriksa lalu memberikan nilai tanpa bertanya dan menjelaskan kelemahan siswa dalam menyelesaikan tugas rumahnya; (3) Guru honorer $65 \%$ bekerja maksimal dalam menyelesaikan tugasnya. Kondisi ini mengidentifikasi guru tidak bekerja dengan baik dalam pembelajaran di kelas.

Perlu diketahui juga peningkatan motivasi kerja guru akan terwujud pada prilaku budaya organisasi yang diarahkan pada pencapai tujuan organisasi. Keinginan guru untuk bekerja dengan baik di sekolah memberikan pencapaian hasil kerja yang maksimal. Ellen Wallach (Sobirin, 2009 : 284) seorang pakar pengembang karir menyuarakan pentingnya motivasi seseorang dikaitkan dengan budaya organisasi tempat kerja. Menurutnya pekerjaan seorang karyawan akan jauh lebih efektif jika terdapat kecocokan antara motivasi karyawan dan budaya organisasi yang berjalan.

Dalam observasi awal di beberapa SD Negeri di Kota Mataram, peneliti menemukan kenyataan bahwa guru masih sering berkumpul di ruang guru saat pelajaran masih berlangsung. Kebiasaan ini dibenarkan beberapa kepala sekolah yang menyatakan bahwa guru berkumpul setelah memberikan bahan catatan di kelas, ketika ditegur guru beralasan mencari bahan yang tertinggal di meja kerjanya. Sehubungan dengan itu hasil pengamatan wawancara awal kepada guruguru di kota Mataram peneliti menemukan keluhan guru-guru yang membahas perlakuan administrasi sekolah yang tidak sesuai dengan keinginan mereka yang menyebabkan para guru terlebih guru honorer kecewa dan sering mengeluhkan perlakuan pihak sekolah yang tidak mengenakkan. 
Sekolah berkesan memerlukan guru pada saat mengajar di kelas, di luar dari itu para guru sering tidak diindahkan. Banyak kegiatan sekolah yang memilliki anggaran diberikan kepada beberapa orang guru yang dinilai loyal kepada kepala sekolah, sedangkan untuk guru yang lain tidak diikutsertakan.

Dari uraian di atas dapat dipahami banyak faktor yang dapat mempengaruhi motivasi kerja guru agar dapat bekerja sesuai tuntunan tugasnya di sekolah dan menjadi guru yang berkualitas dan profesional. Dalam kesempatan ini, peneliti merasa penting untuk mengkaji motivasi kerja guru di SD Negeri di Kecamatan Selaparang Kota Mataram dengan judul: Pengaruh Kepemimpinan Kepala Sekolah dan Budaya Organisasi Terhadap Motivasi Kerja Guru honorer SD Negeri di Kecamatan Selaparang Kota Mataram.

Banyak kajian tentang definisi kepemimpinan yang telah dikemukakan oleh ahli. Yukl (2010: 5) menyatakan kepemimpinan adalah proses untuk mempengaruhi orang lain untuk memahami dan setuju dengan apa yang perlu dilakukan dan bagaimana tugas itu dilakukansecara efektif, serta proses untuk memfasilitasi upayaindividu dan kolektif untuk mencapai tujuan bersama. Kemudian Ordway Tead (Kartono, 2014: 57) mengemukakan bahwa kepemimpinan adalah kegiatan mempengaruhi orang-orang agar mereka mau bekerja sama untuk mencapai tujuan yang diinginkan. Sedangkan menurut Kartono (2014: 57) memberikan definisi bahwa kepemimpinan adalah Kemampuan seseorang untuk mempengaruhi dan mengarahkan tingkah laku orang lain, bawahan atau sekelompok orang.
Ada beberapa tipe kepemimpinan yang sering menjadi perbincangan oleh banyak ahli. Siagian (2010: 31) menjelaskan tentang tipe kepemimpinan yang meliputi limatipepokok kepemimpinan, yaitu sebagai berikut:

1) Tipe Kepemimpinan Otokratik

Kepemimpinan ini menempatkan kekuasaan ditangansatuorang atausekelompok kecilorang yang diantara mereka tetap ada seseorang yang paling berkuasa. Pemimpin bertindak sebagai penguasatunggal. Kedudukan bawahan semata-mata sebagai pelaksana keputusan, perintah dan bahkan kehendakpemimpin. Pemimpin memandang dirinya lebih dalam segala hal, dibandingkan dengan bawahannya.

2) Tipe Kepemimpinan Paternalistik

Tipe kepemimpinan ini lebih mengutamakan kebersamaan. Tipe ini memperlakukan semua satuan kerja yang terdapat dalam organisasi dengan adil dan serata mungkin.

3) Tipe Kepemimpinan Kharismatik

Dalamtipeini pemimpin mempunyai kemampuan menggerakkan oranglaindengan mendayagunakan

keistimewaan atau kelebihan pribadi yang dimilikioleh pemimpin, sehinggamenimbulkan rasa hormat, segan dan patuh pada orang-orang yang dipimpinnya.

4) Kepemimpinan bebas (Laissez Faire)

Dalam kepemimpinan ini pemimpin berkedudukan sebagai simbol. Kepemimpinan dijalankan dengan memberikan kebebasan penuh pada orang yang dipimpin dalam mengambil keputusan dan melakukan kegiatan menurut kehendak dan kepentingan masing-masing, $\backslash$ baik 
secaraperseorangan maupun berupa kelompok-kelompok kecil.

5) Tipe kepemimpinan demokratis

Tipe kepemimpinan ini menempatkan manusia sebagai faktor utama danterpenting dalamsetiaporganisasi. Proses kepemimpinan diwujudkan dengan cara memberikan kesempatan yang luas bagi anggota organisasi untuk berpartisipasi dalam setiap kegiatan. Setiap anggota kelompok tidak saja diberi kesempatan untuk aktif, tetapi juga dibantu dalam mengembangkan sikap dan kemampuan memimpin.

Menurut Taylor (Sobirin, 2009: 50) budaya adalah kompleksitas menyeluruh yang terdiri dari pengetahuan, keyakinan, seni, moral, hukum, adat kebiasaan dan berbagai kapabilitas lainnya serta kebiasaan apa saja yang diperoleh seorang manusia sebagai bagian dari sebuah masyarakat. Sedangkan Stoner (Moeljono, 2003: 16), budaya adalah gabungan kompleks asumsi, tingkah laku, cerita, mitos, metafora, dan berbagai ide lain yang menjadi satu untuk menentukan arti menjadi anggota masyarakat tertentu.

Jadi, dapat disimpulkan bahwa budaya merupakan nilai-nilai dan kebiasaan yang diterima sebagai acuan bersama yang diikuti dan dihormati. Budaya telah menjadi konsep penting dalam memahami masyarakat dan kelompok manusia untuk waktu yang lama.

Menurut Robbins (Sobirin, 2009：5) organisasi adalah unit sosial yang sengaja didirikan untuk jangka waktu yang relatif lama, beranggotakan dua orang atau lebih yang bekerja bersama-sama dan terkoordinasi, mempunyai pola kerja tertentu yang terstruktur, dan didirikan untuk mencapai tujuan bersama atau satu set tujuan yang telah ditentukan sebelumnya. Sedangkan menurut Indriyo Gitosudarmo (Ardana, 2009: 1) organisasi adalah suatu system yang terdiri dari pola aktivitas kerjasama yang dilakukan secara teratur dan berulang-ulang oeleh sekelompok orang untuk mencapai suatu tujuan.

Jadi, dari pendapat ahli diatas dapat ditarik kesimpulan bahwa pengertian Budaya Organisasi adalah seperangkat asumsi atau keyakinan, nilai-nilai dan norma yang dikembangkan dalam organisasi yang dijadikan pedoman tingkah laku bagi anggota-anggotanya untuk mengatasi masalah adaptasi eksternal dan integrasi internal.

Robbins ( 2002 : 55) mengemukakan bahwa motivasi adalah keinginan untuk melakukan seseuatu dan menentukann kemampuan bertindak untuk memuaskan kebutuhan individu. Sementara itu Steiner (Kartono 2014: 107), berpendapat:Amotive is aninner statethat energizes activities ormoves (hence motivation) and that directs or channels behavior to words a goal. Maksudnya kurang lebih bahwa motivadalahsuatukeadaanbatiniahyangmembe rikanenergi kepadaaktivitasaktivitasataugerakan yangmengarahkan atau menyalurkantingkah lakukepada suatu tujuan. Motivasidapat pula berarti sebagai faktor yang mendorongoranguntuk bertindak dengancara tertentu. Menurut Hasibuan (2010: 95) motivasiadalah pemberian daya penggerak yang menciptakan kegairahan kerja seseorang agar mereka mau bekerja sama, bekerja efektif, dan terintegrasi dengan segala daya upayanya untuk mencapai kepuasan. 
Dengan demikian dapat disimpulkan bahwa motivasi adalah mengerakan atau daya dorong yang memberikan semangat kepada seorang untuk mencapai suatu tujuan. Menurut pendapat Robbins dan Culte r(Ardana,2009: 30), Motivasi adalah kesediaan untuk mengeluarkan tingkat upaya yang tinggi, untuk tujuan organisasi yang dikondisikan oleh kemampuan upaya itu dalam memenuhi beberapa kebutuhan individu tertentu.Maksudnya motivasi dengan intensitas yang cukup akan memberikan arah pada individu untuk melakukan sesuatu secara tekun dan kontinyu. American Encyclopedia (Hasibuan, 2010: 96) Mengemukakan kecendrungan ( suatu sifat yang merupakan pokok pertentangan) dalam diri seseorang yang membangkit topangan dan mengarahkan tindakan - tindakannya. Motivasi sangat penting, merupakan dorongan dan daya penggerak yang mempengaruhi tingkah laku tertentu, serta usaha menumbuh kembangkan bagi kehidupan pribadi yang bersangkutan. Ketika sebuah motivasi menimbulkan suatu dorongan aktivitas, berkaitan dengan hal ini Siagian (2004:138)berpendapat motivasi adalah daya pendorong yang mengakibatkan seorang anggota organisasi mau dan rela untuk menggerakan kemampuan dalam bentukkeahlian atau ketrampilan tenaga dan waktunya untuk menyelenggarakanberbagaikegiatan yang menjadi tanggung jawabnya dan menunaikan kewajibanya, dalam rangka pencapaian tujuan dan berbagai sasaran organisasi yang telah ditentukanorganisasi sebelumnya. Jika motivasi rendah maka sulit diharapkan produktifitas kerja yang tinggi.Dalam kehidupan keorganisasian motivasi individu menjadi penggerakbagi usaha untuk melaksanakan tugas dengan iklas dan bersemangat sehingga produktivitas kerja yang dihasilkan dapat maksimal, dengan demikian tujuan organisasidapat diwujudkan.

Berdasarkanpemahaman ini,kegunaan atau fungsi dari motivasi dalam kehidupan seseorangsebagai pendorong agarmelaksanakan sesuatu, menentukan arah perbuatan sehingga dapat meningkatkan hasil kerja, mempercepat proses penyelesaian pekerjaan, dan sarana pengembanganprestasikerja dan pencapaian tujuanorganisasi.

Berdasarkan beberapa pandangan yang telah diuraikan di atas, maka secara umum motivasi kerjaguru adalah kekuatankekuatan atau tenaga-tenaga yang dapat memberikan dorongan kepada kegiatan kerja seseorang guru.Dalam suatu sekolah motivasi kerja seorang guru erat kaitanya dengan kegiatan guru dalam proses belajar mengajar,tentu saja tidak terlepas dari lingkungan organisasi serta usaha pihak organisasi untuk meningkatkan ketrampilanketrampilannya. Sehinggadalam kaitan dengan tugasnya, motivasi kerja guru adalah motivasi untuk melaksanakan tugas-tugas guruyaitu suatu keadaan atau kondisi yang mendorong dan mengarahkan individu dalam melaksanakan tugasnya secara tekun dan kontinyu.

Motivasi kerja memiliki beberapa dimensi.Menurut Uno (2013: 73) dimensi motivasi kerja meliputi motivasi internal dan motivasi eksternal. Motivasi internal memiliki beberapa indikator, antara lain: tanggung jawab guru dalam melaksanakan tugas, melaksanakan tugas dengan target yang jelas, memiliki tujuan yang jelas dan 
menantang, ada umpan balik atas hasil pekerjaan, memiliki perasaan senang dalam bekerja, selalu berusaha untuk mengungguli orang lain, diutamakan prestasi dari apa yang dikerjakannya. Sedangkan motivasi eksternal memiliki beberapa iindikator, antara lain: selalu berusaha untuk memenuhi kebutuhan hidup dan kebutuhan kerjanya, senang memperoleh pujian dari apa yang diikerjakannya, bekerja dengan harapan ingin memperoleh insentif, bekerja dengan harapan ingin memperoleh perhatian dari teman dan atasan.

Berdasarkan pandangan tersebut, maka dimensi motivasi kerja dapat dipandang dalam dua dimensi, yaitu dimensi internal dan eksternal.Kedua dimensi tersebut dapat memberikan gambaran kepada kita dalam memahami tentang motivasi kerja pada diri seorang individu.Pada dimensi motivasi tersebut juga terdapat kekuatan-kekuatan atau tenaga yang dapat memberikan dorongan kepada seseorang dalam melakukan pekerjaan.

\section{METODE PENELITIAN}

Tempat dan Waktu Penelitian

Penelitian ini dilaksanakan di Kota Mataram bertempat di SDN Negeri SeKecamatan Selaparang dengan waktu penelitian direncanakan sejak Pebruari sampai Mei tahun 2015.

Pendekatan Penelitian

Penelitian inimenggunakan pendekatan kuantitatif deskriptif, yaitumengkaji fakta-fakta yang ada, yang akan dideskripsikan dengan menggunakan rumus statistik. Penelitian akan melihat tentang pengaruh dua variabel bebas $(\mathrm{X})$ dan satu variabel terikat (Y). Variabel bebas dalam penelitian ini adalah Kepemimpinan Kepala Sekolah sebagai variabel $\mathrm{X}_{1}$ dan Budaya Organisasi sebagai variabel $\mathrm{X}_{2}$ dengan Motivasi Kerja Guru Honorer sebagai variabel Y. Selain itu, penelitian ini juga menggunakan pendekatan kualitatif deskriptif, yaitu mendiskripsikan fakta- fakta yang ada atas masalah- masalah yang terjadi dilapangan. Hal ini dilakukan dalam rangka mendukung dan memverifikasi data yang diperoleh melalui data kuantitatif. Dengan demikian akan diperoleh trianggulasi data yang akan memperkuat hasil penelitian.

\section{Populasi Penelitian}

Populasi dalam penelitian ini adalah guru-guru honorer yang bekerja di 26 SDN di Kecamatan Kota Mataram dengan Jumlah 79 orang guru honorer. Adapun secara rinci jumlah populasi guru honorer di Kecamatan Selaparang Kota Mataram dapat dilihat pada lampiran 1.

\section{Sampel Penelitian}

Sampel dalam penelitian ini diambil dari guru-guru Sekolah Dasar Negeri yang berstatus honorer (Non PNS) di Kecamatan Selaparang Kota Mataram yang terbagi menjadi lima gugus. Pengambilan sampel dalam penelitian ini menggunakan teknik probability random sampling yaitu memberikan peluang yang sama bagi penulis untuk mengambil setiap unsur (anggota) populasi untuk dipilih menjadi anggota sampel. Oleh karena itu, pengambilan sampel untuk pemilihan anggota sampel peneliti menggunakan Cluster sampling (Area Sampling). Teknik ini digunakan untuk menentukan sampel bila obyek yang akan 
diteliti atau sumber data sangat luas .Untuk mendapatkan jumlahsampel dari 79 populasi guru honorer yang ada, peneliti menggunakan rumus Al-Rasyid sebagai berikut:

$$
n o=\left(\frac{z \alpha}{2 \cdot B E}\right)^{2}
$$

Keterangan :

$\alpha=$ Taraf kesalahan yang besarnya ditetapkan sebesar 0,05

$\mathrm{N} \quad=$ Jumlah populasi $=79$ guru honorer

$\mathrm{BE}=$ : Boud of Error di ambil $10 \%$

$\mathrm{Z} \alpha=$ Nilai dalam tabel $\mathrm{Z}=1,99$

no = Ukuran Sampel

$n o=\left(\frac{z \alpha}{2 \cdot B E}\right)^{2}=\left(\frac{1,99}{2 \cdot(0,10)}\right)^{2}=\quad n o=$ $(9,95)^{2}=99,0025$

danno $=0,05 N=0,05 \times 79=3.95$ karenano $>0,05$ Natau 99,0025 >

3.95 maka besarnya sampel dapat dihitung dengan rumus :

$n=\frac{n o}{\frac{n o}{1+\frac{n o-1}{N}}}=\frac{99,0025}{\frac{99,0025}{1+\frac{99,0025-1}{79}}}=\frac{99,0025}{2,2405}=$

$44,187=45$ orang responden.

Riduwan (2014: 25)

Berdasarkan teknik pengambilan sampel tersebut maka jumlah sampel dalam penelitian ini sebanyak 45 orang responden yang diambil dari 5 gugus sekolah dasar negeri se-Kecamatan Selaparang dimana setiap gugus terdiri dari 9 orang responden.Untuk mendapatkan trianggulasi data peneliti melakukan wawancara dan pengamatan.

\section{RANCANGAN PENELITIAN}

Rancangan penelitian merupakan keseluruhan proses penelitian yang dilakukan mulai dari proses pengumpulan data sampai pada proses pengolahan data dan dilanjutkan dengan merangkum hasil wawancara dan pengamatan data-data sekunder. Rancangan penelitian ini disesuaikan dengan jenis dan tujuan penelitian yang telah ditentukan. Sebagaimana telah dikemukakan bahwa penelitian ini menggunakan pendekatan penelitian kuantitatif dan Kualitatif, maka rancangan penelitian dapat dilihat pada gambar 3.1.
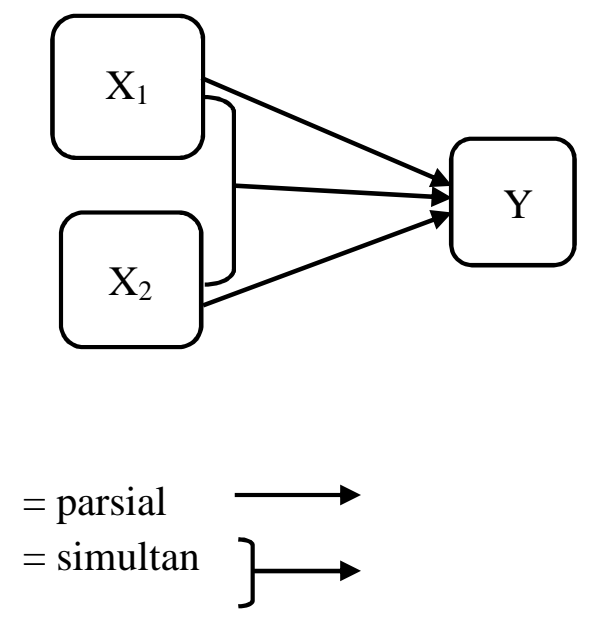

Gambar 3.1

Pola Hubungan Antar Variabel $\left(\mathrm{X}_{1}, \mathrm{X}_{2}\right.$, dan Y).

Keterangan :

$\mathrm{X}_{1}=$ Kepemimpinan Kepala Sekolah

$\mathrm{X}_{2}=$ Budaya Organisasi

$\mathrm{Y}=$ Motivasi Kerja Guru Honorer

Pengujian Validitas dan Reliabilitas Instrumen

1. Uji Validitas

Validitas instrumen dalam penelitian ini ditentukan dengan menggunakan validitas isi,konstrak yang menyangkut isi dan format instrumen.Validitas isi dilakukan dengan mengkonsultasikan instrumen kepada 
akademisi dan praktisi dalam hal ini dosen ahli dan guru.

Validitas daftar pernyataan ini dilakukan dengan menghitung antara skor masing masing butir pertanyaan dengan skor total. Alat analisisnya adalah koefisien korelasi ProductMomentPerson yang di peroleh dengan menggunakan alat bantu SPSS for Windows 16.0.

2. Uji Reliabilitas

Reliabilitas instrumen mengacu pada konsistensi hasil pengukuran yang ditunjukkan oleh instrumen tersebut. Pengujian reliabilitas instrumen dalam penelitian ini menggunakan rumus Alpha Cronbach sebagai berikut:

$\alpha=\left(\frac{n}{n-1}\right)\left(1-\frac{\Sigma V i}{\Sigma V t}\right)$

Keterangan:

$\mathrm{V}_{\mathrm{i}}=$ varian bagian ke I dari tes

$\mathrm{V}_{\mathrm{t}}=$ varian skor total

$\mathrm{n}$ = banyak bagian

(Candiasa, 2010: 67)

Reliabilitas yang digunakan adalah reliabilitas internal yaitu reliabilitas yang diperoleh dengan cara menganalisis data dari satu kali pengambilan data (crosssection). Pengujian reliabilitas juga menggunakan program yang sama yaitu SPSS for Windows 16.0.

Uji reliabilitas instrumen dalam penelitian ini menggunakan rumus Alpha Cronbach, dimana prasyarat untuk mendapatkan persyaratan reliabel didapatkan dengan memiliki nilai Alpha Cronbach > 0.6 (Arikunto, 2006: 123). Ringkasan hasil dua kali hasi uji reliabilitas dengan menggunakan program SPSS for Windows 16.0. dapat dilihat pada tabel 3.6
Tabel 3.6

Hasil Uji Reliabilitas Variabel

\begin{tabular}{|c|c|c|c|c|}
\hline 0 & $\begin{array}{l}\text { Variabe } \\
1\end{array}$ & $\begin{array}{l}\text { Alpha } \\
\text { Cronba } \\
\text { ch I }\end{array}$ & $\begin{array}{l}\text { Alpha } \\
\text { Cronba } \\
\text { ch II }\end{array}$ & Hasil \\
\hline 1 & $\begin{array}{l}\text { Kepemi } \\
\text { mpinan } \\
\text { Kepala } \\
\text { Sekolah }\end{array}$ & 0.972 & 0.923 & Reliabel \\
\hline 2 & $\begin{array}{l}\text { Budaya } \\
\text { Organis } \\
\text { asi }\end{array}$ & 0.958 & 0.933 & Reliabel \\
\hline 3 & $\begin{array}{l}\text { Motivas } \\
\text { i Kerja } \\
\text { Guru } \\
\text { Honorer }\end{array}$ & 0.982 & 0.921 & Reliabel \\
\hline
\end{tabular}

Teknik Analisis Data

Teknik analisis data merupakan bagian penting dalam penelitian ini yang harus dilakukan peneliti untuk mendapatkan data yang valid. Oleh karena itu, beberapa hal yang harus dilakukan penelitiantara lain:

Uji prasyarat akan dilakukan terlebih dahulu untuk menentukan jenis statistik yang digunakan. Hal ini dilakukan sebelum menguji hipotesis.Uji prasyarat dalam penelitian ini meliputi uji normalitas data, uji homoskedastisitas, dan uji multikolinieritas.

Uji normalitas dilakukan untuk menguji sebaran data yang dianalisis berdistribusi normal atau tidak.Uji normalitas dalam penelitian ini menggunakan uji Kolmogorov Smirnov. Kriteria yang digunakan untuk mengambil kesimpulan adalah dengan membandingkan nilai signifikansi dengan nilai derajat kepercayaan yang digunakan adalah 0,05. Jika nilai signifikansi lebih besar dari 0,05 maka skor hasil pengukuran dapat dikatakan 
berdistribusi normal. Perhitungan uji normalitas dalam penelitian ini dilakukan dengan bantuan SPSS.

Heteroskedasitas merupakan

fenomena terjadinya perbedaan varian antar seri data. Heteroskedasitas muncul apabila nilai varian dari variabel tak bebas (Yi) meningkat sebagai meningkatnya varian dari variabel bebas $(\mathrm{Xi})$, maka varian dari $\mathrm{Yi}$ adalah tidak sama. Gejala heteroskedasitas lebih sering dalam data cross section dari pada timeseries. Selain itu juga sering muncul dalam analisis yang menggunakan data ratarata. Untuk mendektesi keberadaan heteroskedasitas digunakan metode grafik scatter plot, dimana apabila nilai probabilitas ( $p$ value) observasi $\mathrm{R}^{2}$ lebih besar dibandingkan tingkat resiko kesalahan yang diambil (digunakan $\alpha=5 \%$ ), maka residual digolongkan

homoskedasitas.Multikolinieritas menunjukkan adanya hubungan sempurna atau dekat sempurna antar variabel bebas. Adanya multikolinieritas biasanya ditandai oleh besarnya nilai $\mathrm{R}^{2}$ disertai banyaknya uji statistik (t) yang tidak signifikan $(\mathrm{P}<0,05)$, kuatnya hubungan korelasi antar variabel bebas $(r \geq 0,8)$ dan signifikan, nilai perhitungan Variance Inflation Faktor (VIF) untuk variabel bebas $\geq 10$, dan nilai perhitungan eigenvalue mendekati 0 diantara variabel bebas (Gunartha, 2013: 8).

Berdasarkan hipotesis yang diajukan dalam penelitian ini, uji hipotesis akan dilakukan dengan analisis regresi ganda. Analisis regresi ganda merupakan analisis untuk mencari hubungan fungsional linier antara satu variabel terikat dengan dua atau lebih variabel bebas.
Analisis regresi ganda digunakan untuk mencari hubungan fungsional linier antara variabel terikat dengan dua atau lebih variabel bebas. Rumus regresi ganda dijelaskan sebagai berikut:

$\mathrm{Y}_{\mathrm{i}}=\beta_{0}+\beta_{1} * \mathrm{X}_{1 \mathrm{i}}+\beta_{2} * \mathrm{X}_{2 \mathrm{i}}+\varepsilon_{\mathrm{i}}$

Keterangan:

$\mathrm{Y}_{\mathrm{i}}$ : variabel terikat $(\mathrm{i}=1,2, \ldots, \mathrm{n})$

$\mathrm{X}_{\mathrm{j}}$ : variabel bebas $(\mathrm{j}=1,2, \ldots, \mathrm{k})$

$\beta_{0}$ : Intercept (rerata umum Y ketika $\mathrm{X}_{\mathrm{j}}=0$ )

$\beta_{1}-\beta_{\mathrm{k}}$ : koefisien regresi untuk masingmasing $X_{j}$

$\varepsilon_{\mathrm{i}}$ : faktor lain di luar model termasuk galat (Gunartha, 2013: 3)

\section{HASIL PENELITIAN DAN PEMBAHASAN}

Tampilan hasil pengolahan data menunjukkan besarnya Adjusted $R$ Square adalah 0,585 hal ini berarti $58,5 \%$ variasi dari Motivasi Kinerja dapat dijelaskan oleh variasi Kepemimpinan Kepala Sekolah dan Budaya Organisai. Sedangkan sisanya $(100 \%$ - 58,5\% $\%=41,5 \%$ ) dijelaskan oleh sebabsebab lain diluar model yang telah dibangun oleh peneliti. Standard Error of Estimate (SEE) sebesar 0,40770. Semakin kecil nilai SEE akan membuat model regresi semakin tepat dalam memprediksi variabel dependen (tabel 4.18).

Untuk mengetahui pengaruh variabel independen (bebas) secara bersama-sama (simultan) terhadap variabel dependen (terikat) diperlukan uji hipotesis menggunakan angka $\mathrm{F}$ sebagaimana tertera dalam tabel di atas. 
berikut:

Hipotesisinya berbunyi sebagai

Ho : Tidak ada hubungan yang linear antara Kepemimpinan Kepala Sekolah dan Budaya Organisasi terhadap Motivasi Kerja

$\mathrm{Ha}$ : Ada hubungan yang linear antara Kepemimpinan Kepala Sekolah dan Budaya Organisasi terhadap Motivasi Kerja

Pengujian dapat dilakukan dengan dua cara. Pertama, dengan membandingkan besarnya angka $\mathrm{F}$ penelitian dengan $\mathrm{F}$ tabel. Cara yang kedua ialah dengan membandingkan angka taraf signifikansi (sig) hasil penelitian dengan taraf signifikansi 0,05 $(5 \%)$.

a. Menggunakan cara pertama atau membandingkan besarnya angka $\mathrm{F}$ penelitian dengan $\mathrm{F}$ tabel

Pertama: menghitung F penelitian

F penelitian dari SPSS didapatkan sebesar 32.009

Kedua: menghitung $\mathrm{F}$ tabel dengan ketentuan sebagai berikut:

Taraf signifikansi dan Derajat Kebebasan (DK) dengan numerator $\mathrm{dk}_{\text {pembilang }}=\mathrm{k}$ (banyak variabel prediktor) yaitu dan denumerator $\mathrm{dk}_{\text {penyebut }}=\mathrm{n}-\mathrm{k}-1$ atau $45-2-1=$ 42. Dengan ketentuan tersebut diperoleh angka $\mathrm{F}$ tabel sebesar 3,22.

Ketiga: menentukan kriteria pengujian hipotesis sebagai berikut:

Jika $\mathrm{F}$ penelitian > F tabel maka Ho ditolak dan Ha diterima.

Jika $\mathrm{F}$ penelitian < $\mathrm{F}$ tabel maka Ho diterima dan Ha ditolak.

Dari hasil perhitungan, didapatkan angka $\mathrm{F}$ penelitian sebesar $32.009>\mathrm{F}$ tabel sebesar 3,22 sehingga Ho ditolak dan $\mathrm{Ha}$ diterima. Artinya, ada hubungan linear antara Kepemimpinan Kepala Sekolah dan Budaya
Organisasi terhadap Motivasi Kerja.Dengan demikian, model regresi tersebut dikatakan sudah layak.

b. Menggunakan cara kedua atau dengan membandingkan besarnya angka taraf signifikansi (sig) penelitian dengan taraf signifikansi sebesar 0,05. Kriterianya sebagai berikut:

Jika sig. penelitian < 0,05 maka Ho ditolak dan Ha diterima.

Jika sig. penelitian > 0,05 maka Ho diterima dan Ha ditolak.

Berdasarkan perhitungan angka signifikansi sebesar $0.000<0,05$ maka Ho ditolak dan $\mathrm{Ha}$ diterima. Artinya, ada hubungan linear antara Kepemimpinan Kepala Sekolah dan Budaya Organisasi terhadap Motivasi Kerja. Dapat dilihat dari pengujian angka $\mathrm{F}$ ataupun angka signifikansi menghasilkan keputusan yang sama.

Dari output ANOVA atau hasil uji $\mathrm{F}$ test didapati nilai $\mathrm{F}$ hitung sebesar 39.009 dengan probabilitas 0,000 . Karena probabilitas jauh lebih kecil dari 0,05 maka model regresi dapat digunakan untuk memprediksi Motivasi Kerja atau dapat dikatakan bahwa Kepemimpinan Kepala Sekolah dan Budaya Organisasi secara bersama-sama berpengaruh terhadap Motivasi Kerja (tabel 4.21).

\section{$\mathrm{Y}=1,194(\alpha)-0,292(\mathrm{KPS})+0,956(\mathrm{BO})+$ 0,415 ( )}

Untuk melihat besarnya pengaruh variabel Kepemimpinan Kepala Sekolah dan Budaya Organisasi terhadap Motivasi Kerja secara sendiri-sendiri (parsial), di gunakan uji $t$.

a. Pengaruh Kepemimpinan Kepala Sekolah tehadap Motivasi Kerja 
Untuk melihat apakah ada pengaruh antara Kepemimpinan Kepala Sekolah tehadap Motivasi Kerja, dapat dilakukan langkah-langkah analisis sebagai berikut:

Pertama menentukan hipotesis:

Ho : tidak ada pengaruh antara

Kepemimpinan Kepala Sekolah tehadap Motivasi Kerja

Ha : ada pengaruh antara

Kepemimpinan Kepala Sekolah tehadap Motivasi Kerja

Kedua: mengihitung besarnya angka $\mathrm{t}$ penelitian

Hasil perhitungan SPSS diperoleh angka t penelitian sebesar 2,391.

Ketiga: menghitung besarnya angka $\mathrm{t}$ tabel dengan ketentuan sebagai berikut:

Taraf signifikansi 0,05 dan Derajat Kebebasan (DK) dengan ketentuan: $\mathrm{DK}=\mathrm{n}-2$, atau 45-2 $=43$. Dari ketentuan tersebut, diperoleh angka t tabel sebesar 2,021.

Keempat: menentukan kriteria

Kriteria uji hipotesisnya sebagai berikut:

Jika $\mathrm{t}$ penelitian > $\mathrm{t}$ tabel maka $\mathrm{Ho}$ ditolak dan Ha diterima.

Jika $\mathrm{t}$ penelitian $<\mathrm{t}$ tabel maka $\mathrm{Ho}$ diterima dan Ha ditolak.

Kelima: membuat keputusan

Didasarkan hasil perhitungan, diperoleh angka $\mathrm{t}$ penelitian sebesar 2,391 >t tabel sebesar 2,021.Oleh karena itu Ho diterima dan $\mathrm{Ha}$ ditolak.Artinya, ada pengaruh antara Kepemimpinan Kepala Sekolah tehadap Motivasi Kerja. Hal tersebut juga konsisten dengan hasil Program Windows SPSS Versi 16.0 yang menunjukkan nilai signifikansi untuk variabel Kepemimpinan Kepala Sekolah sebesar 0,021 $<0,05$.

b. Pengaruh Budaya Organisasi terhadap Motivasi Kerja

Tidak berbeda dengan cara perhitungan diatas, untuk melihat apakah ada pengaruh antara Budaya Organisasi terhadap Motivasi Kerja, dapat dilakukan langkahlangkah analisis sebagai berikut:

Pertama menentukan hipotesis:

Ho : tidak ada pengaruh antara Budaya Organisasi terhadap Motivasi Kerja.

Ha : ada pengaruh antara Budaya Organisasi terhadap Motivasi Kerja

Kedua: mengihitung besarnya angka $\mathrm{t}$ penelitian

Hasil perhitungan SPSS diperoleh angka t penelitian sebesar 7,999.

Pembahasan

Dari Tabel 4.22 Uji t Test (parsial) hasil pengujian hipotesis membuktikan bahwa kepemimpinan kepala sekolah berpengaruh terhadap motivasi kerja guru (MKG) sebesar 2,391yang ditunjukan sebagai thitung dan lebih besar dari pada ttabel sebesar 2,021 (2,391>2,021) dengan taraf signiifkan $0,021<0,05$. Hal ini berarti bahwa semakin tinggi intensitas penerapan kepemimpinan kepala sekolah maka semakin tinggi tingkat MKG Honorer Sekolah Dasar Negeri (SDN) di Kecamatan Selaparang Kota Mataram.Begitu pula sebaliknya, semakin rendah intensitas kepemimpinan kepala sekolah, maka semakin rendah tingkat MKG 
Guru Honorer SDN di Kecamatan Selaparang Kota Mataram.

Temuan penelitian tersebut menggambarkan bahwa kemampuan seorang kepala sekolah dalam memimpin sekolah berpengaruh pada peningkatan kinerja guru.Hal ini juga sebagaimana ditegaskan oleh Uno (2013: 67) bahwa motivasi erat hubungannya dengan perilaku dan prestasi kerja, artinya bahwa makin baik motivasi seseorang dalam melakukan pekerjaanya, maka makin baik pula prestasi kerjanya, atau sebaliknya.

Pada konteks ini dapat dikatakan bahwa kepemimpinan menjadi salah satu faktor penting di dalam suatu organisasi (sekolah).Sebagaimana dikatakan oleh Robbins (2002: 163) kepemimpinan adalah kemampuan untuk mempengaruhi suatu kelompok untuk mencapai tujuan.Lebih lanjut disampaikan bahwa bentuk pengaruh tersebut dapat secara formal seperti tingkatan manajerial pada suatu organisasi.

Berdasarkan pembahasan di atas, dapat disimpulkan bahwa kepemimpian merupaka salah satu faktor kunci yang dapat meningkatkan motivasi kerja seseorang dalam suatu organisasi.Selanjutnya Usman (2010:352) mengungkapkan bahwa salah satu kunci keberhasilan sekolah dalam mencapai tujuannya adalah kepala sekolah.Keberhasilan kepala sekolah dalam mencapai tujuannya secara dominan ditentukan oleh keandalan manjemen sekolah yang bersangkutan, sedangkan keandalan manajemen sekolah sangat dipengaruhi oleh kapasitas kepemimpinan kepala sekolahnya.

Dari tabel 4.22 Uji t Test (parsial) hasil pengujian hipotesis membuktikan bahwa kepemimpinan kepala sekolah berpengaruh terhadap budaya organisasi (BO) sebesar 7,999 yang ditunjukan sebagai thitung dan lebih besar dari pada ttabel sebesar 2,021 (7,999>2,021) dengan taraf signiifkan $0,000<0,05$. Hal ini berarti bahwa semakin tinggi intensitas penerapan budaya organisasi di sekolah maka semakin tinggi tingkat MKG Honorer Sekolah Dasar Negeri (SDN) di Kecamatan Selaparang Kota Mataram.Begitu pula sebaliknya, semakin rendah intensitas budaya organisasi sekolah maka semakin rendah tingkat MKG Guru Honorer SDN di Kecamatan Selaparang Kota Mataram.

Temuan tersebut mengindikasikan bahwa budaya dalam sebuah organisasi harus mampu memunculkan rasa toleransi, kerjasama, lebih- lebih terhadap sistem imbalan yang digunakan individual yang didukung manajemen yang baik terhadap kebijakan program sekolah yang tentunya melibatkan peran serta guru dalam berinisiatif untuk membangun perkembangan sekolah. Perilaku budaya yang baik ini akan mampu mengangkat motivasi kerja guru yang ditandai dengan adanya keterbukaan seorang rekan kerja terhadap kekurangan dalam melakukan tugas, perilaku menjaga hubungan baik dengan rekan kerja agar terhindar dari perselisihan, bersedia menerima gaji yang didapatkan sesuai dengan pekerjaannya tanpa ada rasa buruk sangka terhadap hasil pekerjaan seorang rekan kerja lainnya.

\section{SIMPULAN DAN SARAN}

\section{SIMPULAN}

Berdasarkan hasil penelitian dan pembahasan yang telah diuraikan pada bab 
sebelumnya,makadapatdiperoleh kesimpulan sebagai berikut:

1. Terdapat pengaruh kepemimpinan kepala sekolah terhadap motivasi kerja guru honorer SDN di Kecamatan Selaparang Kota Mataram yaitu sebesar2,391 dengan taraf signifikan $0,021<0,05$.

2. Terdapat pengaruh budaya organisasi terhadap motivasi kerja guru honorer SDN di Kecamatan Selaparang Kota Mataram yaitu sebesar 7,999 dengan taraf signifikansi $0,000<0,05$.

3. Terdapat pengaruh kepemimpinan kepala sekolah dan budaya organisasi terhadapmotivasi kerja guru honorer SDN di Kecamatan Selaparang Kota Mataram yaitu sebesar 39,009 dengan signifikansi sebesar $0.000<0,05$.

Implikasi teoritis dalam penelitian ini merupakan kontribusi hasil temuan penelitian terhadap perkembangan ilmu dan dampak hasil penelitian terhadap kebijakan yang ada.Kesimpulan penelitian ini menunjukkan bahwa variabel kepemimpinan memiliki pengaruh terhadap variabel motivasi. Kesimpulan ini memperkuat pendapat dari Yukl yang menyatakan bahwa kepemimpinan adalah proses untuk mempengaruhi orang lain untuk memahami dan setuju dengan apa yang perlu dilakukan dan bagaimana tugas itu dilakukan secara efektif, serta proses untuk memfasilitasi upaya individu dan kolektif untuk mencapai tujuan bersama. Artinya, hasil dari pengaruh tersebut akan melahirkan dorongan untuk mau bekerja demi kepentingan organisasi. Hasil penelitian dapat dijadikan dasar untuk memperbaiki pola kepemimpinan yang ada pada organisasi sekolah.

\section{SARAN}

Berdasarkan kesimpulan penelitian di atas dapat disarankan hal-hal sebagai berikut: 1. Perlu adanya peningkatan kualitas kepemimpinan yang ada ditingkat sekolah agar dapat meningkatkan motivasi kerja guru. Hal ini sebagaiman dibuktikan dari hasil penelitian ini.

2. Budaya organisasi dibandingkan kepemimpinan kepala sekolah memilikiandil yang sangat kuat dalam membentuk motivasi kerja guru honorer, yang pada akhirnya guru semangatmengajar. Oleh karena

itu,budaya oraganisasiharus diperhatikan dan tingkat lagi.

3. Kepemimpinan kepala sekolah dan budaya organisasi harus mampu bersinergi dengan visi dan misi yang ada di sekolah sehingga mampu mempersatukan seluruh aggota masyarakat salah satuya guru honorer sehingga mampu meninggkat kualitas pekerjaan dalam sebuah organisasi sekolah tersebut.

\section{DAFTAR PUSTAKA}

Ardana, Komang dkk. 2009. Perilaku Keorganisasian Yogyakarta : Grahallmu.

Arikunto, Suharsini. 2006. Prosedur Penelitian Suatu Pendekatan Praktek. Jakarta: Rineka Cipta.

Candiasa, Made I. 2010. Pengujian Instrumen disertai Aplikasi Iteman dan Bigstep. Denpasar : Universitas Pendidikan Ganesha. 
Gunartha, I. G. 2013. Panduan Singkat Penggunaan SPSS Untuk Analisis Data Penelitian. Mataram: Tidak Diterbitkan.

Hasibuan,Malayu.S.P. 2010. Organisasi \& Motivasi: Dasar Peningkatan Produktivitas. Jakarta: Bumi Aksara.

Usman, Husaini. 2010.Manajemen Teori, Praktik danRisetPendidikan. Jakarta: Bumi Aksara.

Kartono, Kartini. 2014. Pemimpin dan Kepemimpinan: Apakah Kepemimpinan Abnorma Itu?. Jakarta: Rajawali Perss.

Moeldjono, Djokosantoso. 2003. Budaya Korporat dan Keunggulan Korporasi. Jakarta :PT.Elex Media Komputindo.

Mulyasa. 2013. Manajemen dan Kepemimpinan Kepala Sekolah.Jakarta : Bumi Pendidikan. Jakarta: Bumi Aksara.

Riduwan, 2014. Dasar - Dasar Statistika. Bandung: Alfabeta.

Robbins, Steaphen P. 2002. Prinsip-Prinsip Perilaku Organisasi Edisi Kelima. Jakarta: Erlangga.

Sagala, Syaiful. 2012.Administrasi Pendidika $n$ Kontemporer. Bandung: Alfabeta

Sahertian, Piet A. 2010. Konsepdasa dan xsupervise pendidikan dalam rangka pengembangan sumber daya manusi. Jakarta : RinekaCipta.

Siagian, Sondang P. 2010. Teori dan Praktek Kepemimpinan. Jakarta. Rineka: Cipta.
Sobirin, Achmad. 2009. Budaya Organisasi: Pengertian, Makna dan Aplikasinya dalam Kehidupan Organisasi. Yogyakarta: STIM YKPN.

Sutrisno, Edy. 2011. Budaya Organisasi. Jakarta : Kencana Prenada Media Group.

Tika, Moh. P. 2006.Budaya Organisasi dan Peningkatan Kinerja Perusahaan. Jakarta: Bumi Aksara.

Tunggal, Amin Widjaja. 2007. Corporate Culture Konsep dan Kasus. Jakarta:University.

Uno, Hamzah B. 2009. TeoriMotivasi \&Pen gukurannya: Analisis di Bidang USA: McGraw Hill-International.

Yukl

Gary. 2010. KepemimpinanDalamOrganis asi. (Budi Supriyanto, penerjemah). Jakarta: PT. Indeks. 